\title{
"Students Are My Life": Reflections of One Novice EFL Teacher in Central America
}

\section{Thomas S. C. Farrell E Vanja Avejic}

This paper presents a case study that examined the principles and practices of one novice English as a foreign language (EFL) teacher at a prominent English language institution in Central America. More specifically, this qualitative study sought to contribute to the discussion of the perceived interdependent influences of EFL teachers' thoughts and behaviours through five stages of self-reflection using Farrell's (2015) framework for reflective practice. Overall, the findings suggest that the teacher's stated principles related to her philosophy, beliefs, and theory converge with her classroom practices; however, areas of divergence were also observed. Recommendations are included on the usefulness of the framework for English as a second language (ESL) teachers when reflecting on their practice.

Cet article présente une étude de cas qui s'est penchée sur les principes et les pratiques d'une enseignante d'anglais langue étrangère (ALE) débutante dans une institution de langue anglaise renommée d'Amérique centrale. Plus particulièrement, cette étude qualitative a cherché à contribuer à la discussion sur les influences interdépendantes perçues des pensées et des comportements des enseignants d'ALE à travers cinq étapes d'autoréflexion à l'aide du cadre de pratique réflexive de Farrell (2015). Dans l'ensemble, les résultats suggèrent que les principes énoncés de l'enseignante liés à sa philosophie, à ses croyances et à sa théorie convergent vers ses pratiques en salle de classe; cependant, on a aussi observé des zones de divergence. Nous avons inclus des recommandations sur l'utilité du cadre pour les enseignants d'anglais langue seconde (ALS) lorsqu'ils réfléchissent à leur pratique.

Keywords: reflective practice, teacher education/development, teacher beliefs and practices

Reflective practice generally means that teachers take the responsibility of looking at their professional practice, and the underlying philosophy, beliefs, and theories that shape that practice both inside and outside the classroom so that their professional practice can become personally meaningful (Farrell, 2015; 2018a; 2018b). As Freeman (2016) maintained, reflective practice offers a way into the less "accessible aspects of teacher's work" (p. 208). While reflective practice now enjoys prominence in the field of TESOL, just as in the field of general education, scholars have struggled to come to a consensus on how to implement/operationalize reflective practice for language teachers (Mann \& Walsh, 2013). One of the reasons for this continued struggle with 
its implementation in the field of TESOL is that there has been a hodgepodge of diverse strategies and approaches, so diverse that we still cannot agree on what or how TESOL teachers should be reflecting (Akbari, 2007). Indeed, most, if not all, of these approaches are retrospective in nature, and as Akbari (2007, P. 193) pointed out, many "current reflective models in L2 teacher education lack the necessary critical dimension." This "critical dimension" should include teachers reflecting beyond looking at "what works" and "what does not work" in their teaching (Zeichner \& Liston, 2014). In order for language teachers to become critically reflective, as Bartlett (1990) suggested, they must "transcend the technicalities of teaching and think beyond the need to improve our instructional techniques" (p. 204). This paper applies a relatively new reflective framework designed for language teachers that includes such a critical dimension (Farrell, 2015) as a lens for the reflections of one novice English as a foreign language (EFL) teacher in Costa Rica, Central America, on her sudden transition into online teaching because of the onset of COVID-19.

\section{Reflective Practice}

In the past few decades reflective practice has become a fixture in the field of education, and as Tabachnick and Zeichner (2002) noted, "there is not a single teacher educator who would say that he or she is not concerned about preparing teachers who are reflective" $(\mathrm{p}, 13)$. Indeed, ZwozdiakMyers (2012, p. 3) pointed out that reflective practice is central to a teacher's development because it helps teachers "to analyse and evaluate what is happening" in their classes so that they can not only improve the quality of their teaching, but also provide better opportunities for their students to learn. Over the years, reflective practice has taken a firm hold within teacher preparation and development programs as being an essential skill to foster (Loughran, 2002). Loughran (2002) suggested that within the field of education, reflective practice is a "meaningful way of approaching learning and teaching so that a better understanding of teaching, and teaching about teaching, might develop" (p. 34). That said, although reflection or reflective practice has gained such prominence in the field of education as a mark of professional competence and is considered a significant component of many foundational and in-service education programs and practices, there is still not much agreement about what reflective practice is, and what strategies actually promote reflection (Hébert, 2015). As Hébert (2015) pointed out, "in contemporary educational discourse, reflection lacks a uniform definition" (p. 1-2).

The concept of reflective practice has also been embraced enthusiastically in the field of language teaching with most TESOL teacher educators in agreement that some form of reflection is desirable. However, just as in the field of education where the concept of reflective practice remains a "fuzzy 
concept" (Collin \& Karsenti, 2011, p. 570), in the field of language teaching, "what it actually is and how it might be developed are more problematic" (Walsh \& Mann, 2015, p. 351). For example, many of the reflective approaches that have been proposed are retrospective in nature and purport to offer a structured way for teachers to reflect on their practice by asking them to answer simple questions that mostly focused on "fixing" problems in their teaching behaviours rather than about themselves as teachers (Farrell, 2019). Such "post-mortem" (Freeman, 2016, p. 217) approaches confine reflective practice to merely a problem-solving approach (or "reflection-as-repair") because it only focuses on what the teacher is observed doing, or the technical competencies of teaching, yet it ignores the teacher-as-person behind those classroom actions. Such a narrow, one-dimensional approach to reflection where teachers fill out checklists of ritualized questions neglects the "being" or "person-as-teacher" (Farrell \& Kennedy (2019). As Farrell and Kennedy $(2019$, p. 2) have recently summarized this within the field of TESOL, in many of the adopted approaches, the "teacher (or person-as-teacher) has been separated from the act of teaching, and the act of reflective practice has become 'routinized', as teachers are encouraged to only answer retrospective questions about their practice (such as what happened, why did this happen, what comes next) in order to 'improve' their teaching."

Thus, a more holistic approach to reflective practice where language teachers are considered whole persons, and language teaching to be examined in multidimensional angles including reflection on the moral, ethical, and political aspects of practice is necessary. One such recent holistic approach to reflective practice in the field of TESOL is Farrell's (2015) framework for reflecting on practice. This framework acknowledges the inner life of teachers and not only focuses on the intellectual, cognitive and metacognitive aspects of practice that many of the other approaches focus on, but it also includes the spiritual, moral, and emotional non-cognitive aspects of reflection (Farrell, 2015). As Wright (2010) pointed out, reflective practice must focus not only on classroom teaching behaviours, but also on a teacher's previous learning and life experiences, or their inner lives, so that the teacher can become more selfaware in order to be able to better understand, interpret, and even reshape their professional practice.

This framework has five interconnected levels: philosophy, principles, theory, practice, and beyond practice. The first stage of the framework, philosophy, examines the teacher-as-person because a teacher's basic philosophy has developed since birth. This stage can be considered a "window to the roots of a teacher's practice because a philosophy of practice means each observable behavior has a reason that guides it even if it is implicit" (Farrell, 2019 , p. 84). The second stage, principles, encompasses a teacher's reflections of beliefs about teaching and learning English as a second language. All teachers hold beliefs about their work, students, subject matter, and their roles and responsibilities (Pajares, 1992). The third stage requires teachers 
to reflect on theories that underlie their practice, lesson planning, choice of activities, techniques, and methods. Teachers can also examine critical incidents, or any unplanned events that happen during a class, outside a class, or during a teacher's career that is vividly remembered. The fourth stage, practice, examines a teacher's observable actions while teaching. This stage is strongly connected to the first three stages as development of awareness of the convergence or divergence between belief and practice is the start of "a process of reducing the discrepancy between what we do and what we think we do" (Knezevic, 2001, p. 10). The final phase, beyond practice or critical reflection, explores the moral, political, emotional, ethical, and social issues that impact teachers' practice both inside and outside the classroom. These issues have been neglected in the field of TESOL, yet TESOL teachers must deal with them on a daily basis.

\section{Research Methodology}

This study utilizes a qualitative research approach in order to gain insight on how reflective practice affects novice teachers' experiences in Central America. A case study approach (Merriam, 2009) was the chosen research method due to the descriptive and heuristic nature of reflective practice (Maxwell, 1992) as well as its ability to shed light on the complexities of teacher reflections because of the rich contextualization within a specific population and setting. Although generalizability of case study research to the general population can be difficult (Mackey \& Gass, 2015), it has been successfully applied by other TESOL scholars (e.g., Lamb, 2007; Tsui, 2007) and researchers investigating reflective practice (e.g., Farrell \& Kennedy, 2020; Farrell \& Yang, 2019) using Farrell's (2015) framework (e.g., Farrell \& Kennedy, 2019; Farrell \& Macaplinac, 2021). As van Lier (2005) pointed out, rigorous analysis of a case study of just one teacher can provide in-depth insights into intricate pedagogical and contextual issues that "cannot be done adequately in any other common research practice" (p. 195).

\section{Participant and Context}

The participant in the study, Isabella (a pseudonym), a female English as a foreign language (EFL) teacher whose first language is Spanish with 2 years of teaching experience in a prominent institution in Costa Rica, Central America. Isabella completed an undergraduate degree in a second language and is currently working part-time on a master's degree while teaching. EFL teachers are contracted to teach up to three 3-hour classes every day except Sunday. For example, Isabella starts her day at 9 a.m., teaching in 3-hour blocks with breaks in between until 9 p.m. Teachers have access to coaches as well as school administrators who can help them reflect on specific practices through observation. Isabella has described these coaches as the "moms of 
the school" because they are a resource that she can rely on to improve her teaching practice. Classes typically have 10 students and are taught fully in English, occurring up to 3 times a week depending on the level and course. Isabella expressed interest in the study because she wants to explore different avenues of professional development outside of the current institution she works for.

\section{Data Collection}

Data collection was 1-month long and included transcribed semi-structured interviews and follow-up interviews, written reflection tasks, and virtual classroom observations in line with reflective framework (Farrell, 2015). A total of six interviews were conducted (Merriam, 2009): one preinterview to clarify basic information and five follow-up interviews following each stage of reflective practice framework. All interviews were conducted and recorded via Zoom and lasted between 30 to 45 minutes and then transcribed (Maxwell, 1992). In addition, three different classes per week were observed online in real time as Isabella gave us access as a guest for each of these classes. Prior to the observations, Isabella got permission from her students and informed them that the purpose of the study was to observe the teacher's actions, and it was not concerned with the students' behaviour. In addition, during these observed lessons, we chose the option to not display our video or use audio during the online lesson to minimize the risk of interference. Indeed, we note that there is currently no research that we are aware of in the field that involves an investigator's presence in an online classroom, specifically in Zoom, presumably because the COVID-19 pandemic is an unprecedented circumstance. We later transcribed each recorded class to document not only her actual classroom actions but also to compare these actions to her stated philosophy, principles, theory, and beyond practice reflections. Isabella also completed six written reflection tasks that explored her philosophy, principles, theory, and beyond practice within Farrell's (2015) framework. Written work was then emailed to the researchers and later used as a springboard for questions to be asked in follow-up interviews.

\section{Data Analysis}

Data analysis consisted of seeking responses to the one overarching research question: What are one novice EFL teacher's reflections as expressed through her philosophy, principles, theory, practice, and beyond practice? Data analysis started with inductive discovery to primarily deductive (Merriam \& Tisdell, 2009) while coding. More specifically, data were coded using a priori theory to structure initial levels of coding scheme, and later organized into different categories according to the stage of framework for reflective practice which was, "open, axial, and selective" (Merriam, 2009, p. 200). In addition, for each observed lesson, we had access to the teacher's lesson plan to help 
us analyze the objectives and compare her intentions with what she actually delivered during the lesson. In order to make sense of the data, recurring patterns were then grouped and compared against the research question. Member checking was used as a means of confirming the validity of the data (Lincoln \& Guba, 1985). In this stage of the process, the findings were shared with Isabella to allow her to confirm or refute the accuracy of the data reported in each section of the findings.

\section{Findings}

The findings are presented as answers to the main research question: What are one novice EFL teacher's reflections as expressed through her philosophy, principles, theory, practice, and beyond practice?

\section{Philosophy}

Isabella described herself as a leader and someone who loves working with people. Isabella realized she was a leader early in her university career. She described a situation where she initiated the distribution of tasks in a group project which then continued throughout her university career and family life as many would seek her guidance in similar situations. Although Isabella could not recall the exact moment where she realized she loved working with people, she said, "I don't see teaching as I want you to learn something, but rather I want to help you learn something." Isabella does a lot of volunteer work in the community, and recently accepted a position to work with a group of underprivileged students. She said that she is happy to work with these groups "even if it means working on a Friday night"; Isabella continued, "My students are my life." Isabella stated that her compassionate nature was inspired by her parents who were unable to go to school, as she said, "I would've wanted my parents to have the chance that these kids have of a scholarship and for someone to take them seriously."

Although teaching was not Isabella's first career choice, she identified a positive role model who helped her discover that passion. Isabella was hired by the current institution she works at without any teacher training as her undergraduate degree was in English literature. She stated that the institution saw "potential in her" and paired her with a coach who guided her through many hurdles of teaching and inspired her to "be the best teacher she can be." When asked to comment on what ways this role model impacts her teaching, she stated the following:

I think having somebody who is given the extra mile for us teachers is definitely inspiring for us to do it as well... and he also gives us, he's super creative, like and everybody agrees on that, you talk about him and everyone's like yeah, super creative and committed. He gives us a lot of ideas for our teaching as well. so yeah so having this person gives the extra mile inspires you to do the same. 


\section{Principles}

This section reports on Isabella's reflections on her stated principles as outlined in Table 1 below.

Table 1

Isabella's Stated Principles

\begin{tabular}{|c|c|}
\hline Theme & Principles \\
\hline Language Teaching & $\begin{array}{l}\text { - } \quad \text { Teachers have a "calling" to be a teacher. } \\
\text { - } \quad \text { A teacher is a "doctor." } \\
\text { - } \quad \text { Classroom time is used for "teaching only." }\end{array}$ \\
\hline Language Learning & $\begin{array}{l}\text { - Learning English is like "painting a drawing." } \\
\text { - Students are "patients" with different conditions, } \\
\text { possibilities, and abilities. } \\
\text { - } \quad \text { 11 (first language) is a tool to help L2 (second language) } \\
\text { learning. } \\
\text { - Successful learning means students internalize the } \\
\text { lesson and adopt it to everyday use. }\end{array}$ \\
\hline Teaching L2 Speaking & $\begin{array}{l}\text { - "Rule-based" approach (i.e., correcting oral errors) is } \\
\text { effective for pronunciation. } \\
\text { - } \quad \text { Retaining accent is part of personal identity. }\end{array}$ \\
\hline
\end{tabular}

As summarized in Table 1 above, Isabella expressed various principles, the first of which is related to language where she said she believes that teachers have a "calling" to the profession. Isabella stated that a "calling" entails a teacher "being committed to the task of teaching and uses personal abilities and talents to make the experience as effective as possible." Next, she described herself metaphorically as an "intern" transformed into a "doctor" in the classroom to "find the medicine to make students proficient." When asked to elaborate on her metaphor, she stated that it came from "the idea of different people, different ideas, different backgrounds, getting to know their situation and needs." Interestingly, Isabella added that "doctors are not immune" and require checkups and medicine. When asked about her teacher immunity, she stated that she gets "checkups" through various trainings provided by the institution, consulting with other colleagues, and learning from her students. Lastly, Isabella expressed that she does not use classroom time for anything that is not related to teaching. When asked to elaborate, Isabella described a teacher from her past that would use class time to talk about Halloween costumes:

I was like class time class time and I need this class! Sometimes we have the opportunity to share but I don't want to take class time 
for me telling my life. Or if I didn't prepare, me improvising class, I

hated that when I was a student I don't want to do it myself.

The second theme that emerged was language learning in which Isabella expressed, "learning English is like painting a drawing." Isabella stated that "each class you get the right colors for different sections" and that "you never end painting because you add details." Synonymous with her personal metaphor of a doctor, Isabella described her students as "patients" who have "different backgrounds, stories about learning English, abilities, conditions, and learning styles" which impact language learning. Interestingly, Isabella expressed concern over the "demonization" of the use of L1 when learning an L2. Isabella said that she believes "this is the only tool they have" and she went so far as to personally take a class in another language that restricts L1 in order to get the reaction of what her "students are going through." Overall, Isabella believes that successful learning occurs "the moment when a student internalizes the class and adopts it to their daily use."

Another theme that emerged was a "rule-based" approach towards L2 speaking and especially pronunciation. Isabella said that she finds rule-based approach the most effective because "in Spanish, everything is pronounced as it is written," something that is contrary to English. When Isabella noticed that her students are struggling with a specific item of pronunciation, she "sets aside a specific amount of time and explains it because it's processed completely differently." Although Isabella adapts a rule-based approach for L2 speaking, she is "against the belief that [her students] should talk like a native speaker," and she encourages them "not to lose their accent" and to "not feel bad if they sound Latino because it's who they are."

\section{Theory}

Isabella reflected on her theories of teaching in the third stage of Farrell's (2015) framework by describing her teacher planning approaches. Isabella said that she does not plan the same way as she did when she began to teach due to factors like resources and colleagues. In her written answers Isabella said, "I must make decisions based on what I have available, not precisely according to the beliefs I have adopted from theory." She added that "many factors affect when trying to apply certain practices to class." When asked to expand on this reflection, she explained that she had a hard time planning due to lack of resources at a previous institution when she was a trainee teacher. More specifically she said that she had to buy markers and material for students: "I had to buy that all myself"; she could not plan and she "couldn't even have a presentation because she had to write down everything. She continued: "I didn't have a computer, projector, I only had a whiteboard." Now, Isabella has access to many types of material. She described that she asked for materials 15 minutes before her class such as " 20 permanent markers, colored sheets of paper to decorate, and magazines," and she explained, "if I didn't have 
these resources I wouldn't be able to plan for this type of activities." Further, colleagues from different levels often collaborate while planning to provide students with more opportunities for language use:

Sometimes we have contests, like, who gets to plan the best wedding with a specific budget and we have other groups visiting and the other group are the ones who vote. And they provide the reasons for their blah blah blah and so on. But it's not always that a teacher has the opportunity to do such a thing.

\section{Practice}

For the practice stage of reflection, three lessons all 3 hours in length were observed. All lessons, topics, vocabulary, and grammar structures are predetermined on a course syllabus given by the institution. The teacher is required to cover the syllabus but has the freedom to design activities to present the material. Observations for Isabella were done with one in her lowlevel (level 2) and two in her high-level (level 12) classes. Table 2 summarizes the main categories observed during classroom observations.

Table 2

Isabella's Practices

\begin{tabular}{llll}
\hline Practices & $\begin{array}{l}\text { Lesson 1 } \\
(\text { Level 2) }\end{array}$ & $\begin{array}{l}\text { Lesson 2 } \\
(\text { Level 12) }\end{array}$ & $\begin{array}{c}\text { Lesson 3 } \\
\text { (Level 12) }\end{array}$ \\
\hline Follows lesson plans & $\mathrm{N}$ & $\mathrm{N}$ & $\mathrm{N}$ \\
Gives feedback to students & $\mathrm{O}$ & $\mathrm{O}$ & $\mathrm{O}$ \\
Corrects errors & $\mathrm{O}$ & $\mathrm{O}$ & $\mathrm{O}$ \\
Clearly states instructions & $\mathrm{O}$ & $\mathrm{O}$ & $\mathrm{O}$ \\
Available to students & $\mathrm{O}$ & $\mathrm{O}$ & $\mathrm{O}$ \\
Engages in informal interactions with students & $\mathrm{N}$ & $\mathrm{O}$ & $\mathrm{O}$ \\
Language taught through repetitive drills & $\mathrm{N}$ & $\mathrm{N}$ & $\mathrm{N}$ \\
Classroom management issues & $\mathrm{N}$ & $\mathrm{O}$ & $\mathrm{O}$ \\
\hline \multicolumn{1}{c}{ Note: $\mathrm{O}=$ Observed; $\mathrm{N}=$ Not observed } & & &
\end{tabular}

As Table 2 indicates, in each of the three lessons observed, Isabella diverged from her original lesson plans and activities (which she shared with us prior to each of the lessons observed). However, in all instances this divergence was because of some unanticipated issues with online lessons especially related to providing feedback and correcting errors, which happened in most of the lessons. In addition, in all three lessons Isabella did not use any drilling techniques although she stated that a rule-based approach is most effective for language learning. 
Isabella said that she plans for a specific time for feedback in all her classes especially with lower levels. She also noted that since she shares the same L1 as her students, she can predict what takes more time. For example, " $v$ " sounds will be articulated as " $b$ " as well as an inability to discriminate between "a" and "an." Isabella does not think that this online environment provides them with the same interaction as in face-to-face classes, and therefore it will take more time. The online environment also takes away her ability to provide feedback on the whiteboard, thus she must resort to making recasts, such as repeating the question, repeating the word, changing intonation and the like until her students can better understand any oral mistakes. Additionally, in all three lessons, Isabella diverged from her lesson plan in terms of timing due to feedback. When reflecting on what changes she would make to this lesson, Isabella commented as follows:

Virtual is so slow. The amount of time that they took to complete, and I was visiting, I saw that they were working and not wasting time, but they were like, oh my god, how do I do this? So, in class the first activity would have taken a lot less.

Isabella said that she strives to create a safe environment even in an online environment, and by doing so, she makes herself available to students as in each of her observed lessons. When asked to reflect on how she created a safe environment in each of her lessons, she says she utilizes various classroom management strategies:

Well I think that I reminded them that they can ask questions with the microphone and if they don't feel safe, they can use the chat. And when I go to the breakout rooms I say, "hi guys you're doing okay?" and then I go and then I come back. So, like reminding them that they can ask if they are not feeling sure about what they're going say ... to give them confidence about what they're going to present later.

Furthermore, Isabella was observed personalizing her lessons by making a song playlist for each of her classes to avoid silence in the main session on Zoom. She allows students to email her suggestions of songs which she compiles on Spotify, she then plays the songs while students are working on their tasks. She said that not only does this help her minimize her teacher talk, it also "makes students feel important to the class."

Despite Isabella's best efforts, however, some classroom management issues were observed and one incident in particular that occurred in a higherlevel class (level 12) is worth mentioning. While teaching this higher-level 12 class, Isabella encountered a critical incident in which a student was being disruptive and was attempting to make some inappropriate comments, but she did not take action at that time because Zoom was a new platform for her teaching, and as such, she was unsure how to handle it. However, after that particular lesson, Isabella noted that had this occurred in her regular 
classroom (i.e., not online) she would have handled the situation much differently, as she stated,

I really, really, believe that if we were in regular classes I would've talked to him. I mean we are online I just don't want to make a mess. But if we were in class, I would've pulled him aside and said either you control your comments, this is not appropriate, we don't need this.

\section{Beyond Practice}

In the final stage of Farrell's (2015) framework, Isabella reflected on aspects beyond her practice. For this level of practice, Isabella explored how she perceives power dynamics of Central American society relate to her life as a language teacher. Isabella stated that "societal pressure is one of the most important aspects when considering a career as a teacher." She noted that a unique challenge of being an English teacher in a Latin American country is that her identity is at stake and that speaking English means "leaving your roots behind." She also mentioned that some people in her home country "reject English at all costs" and even recalled a moment at a local café where she was treated differently for speaking English:

Then in university they tell me about my roots and sometimes a word in English slips or if I talk in English in a café with my coworkers, they will point out us as so lame. And I was thinking. Why if you see a group of doctors talking about surgeries, they don't get condemned for that? This is my major. It doesn't mean I'm leaving behind my identity. It's just me talking about my major, not my identity. So, it's a very blurred line not to leave behind who you are and get slowed by this culture that is hitting us so hard.

Although Isabella realized that the world is "becoming a globalized society that requires its citizens to be bilingual," she always tells her students that learning English is not synonymous with the loss of identity. By looking at power dynamics at a sociocultural level, Isabella remarked, "teachers are never the product of a single idea, institution, or experience, we are molded by our social background" and that this career comes with "great responsibility that affects the lives of students."

\section{Discussion}

Overall, the findings from this study indicate that Isabella's principles about language teaching and learning mainly converged with her classroom practices despite the sudden transition to an online learning environment (i.e., lessons conducted on Zoom) because of COVID-19. There could be several 
reasons for this convergence such as prioritizing student needs to ultimately create a student-centered online environment, which Isabella attributes to her upbringing. Isabella described life in high school as a "roller coaster at times" and because of her early school experiences, she takes into account her students' individual needs because as she said, "that's what I needed back then but I was always frowned upon." In terms of theory, Isabella noted that she is always trying to adapt her teaching approaches to match her student needs. For example, she adapted activities through "Menti" because she noticed that it was "highly engaging" for her students. More specifically, her regard for student needs was demonstrated in her practice as she made herself available even in an online environment. Isabella utilized a feature on Zoom called "chat room" where students could privately message her. During the beyond practice stage, Isabella reflected on how the transition to an online classroom affected her students. She said that the transition to an online environment was "emotional" and that she became an "IT expert" for many of her students. Thus, despite these environmental changes, Isabella's principles about language teaching and learning converged with her practice due to her upbringing and personal experiences which resulted in rapport building with students online.

While there were consistencies between reflections and actual practice, there were also some areas of divergence, but mainly related to not following her pre-stated lesson plans that mirrored the institution's prescribed syllabus. The case study outlined and discussed above used Farrell's (2015) framework as a means for Isabella to explore and reflect on her practice. The idea of engaging in such reflections is that as Isabella moved through the framework, she became more aware of her principles and her practices so that she can make her own informed decisions about her teaching and her students' learning. Isabella explored what has shaped her since birthher socioeconomic background, ethnicity, family and personal valuesand how all of these impacts how she got to where she is now. In other words, reflecting at this stage of the framework allowed Isabella to become more aware of her philosophy and what has shaped her as a person. She then moved on to explore her principles, or in Farrell's (2015) words, her "assumptions, beliefs, and conceptions about teaching and learning" (p. 51), which are closely linked to her philosophy, as teaching and learning beliefs are also shaped by an individual's background. Thus, reflecting on a teacher's principles is important because it reveals why a teacher does what she does in a lesson. This is especially important for a language teacher's reflections as it can help the teacher trace back the origins of her instructional decisions to her early years of education. For example, the findings above reveal that there was divergence between Isabella's stated principles of rulebased approaches and her actual classroom practices, and this discrepancy can be traced back to her own second language education experiences where she was taught prescriptive English grammar mainly through drilling and a 
rule-based approach. As a result, she may have believed that it is important to do the same in her own English language teaching at the time when she was interviewed at the principles stage of the framework. However, during and after the practice stage, Isabella began to realize that these methods and approaches related to prescriptive grammar teaching were not conducive to a positive language learning environment for her and her learners. During the post-project interview when she was reviewing all the findings, she remarked that "the 'ghosts' of her past as a learner still creep into [her] current teaching." When asked to elaborate what she meant by these "ghosts," Isabella said,

I was taught this is the verb to be and this is the subject you use "are". This is where I use the verb to be oh wow. I know how it works because of class but I don't know how to use it because of class. I know this is not effective. And sometimes I'm talking about grammar and I'm like, how are they supposed to know when to use this if I'm not giving them context. But I go back to the way that I experience teaching so and I call it a "ghost" because it's not good. It's something that I have to control, and I think I do it a lot because the book does not allow me to see the context.

Such reflections have caused her to question her principles related to language teaching and learning as she moves out of her original comfort zone, and we suspect this process of questioning has just begun for Isabella. In addition, Isabella's reflections on her philosophy and her principles inform her theory (the third stage of the framework) as she developed her lesson plans prior to delivering her lessons. For Isabella for the most part, lesson plans and delivery strategies are dependent on a predetermined course syllabus created by the curriculum development department in their institution, and she has no real influence on how these are determined. This may account for her divergence from each of the presented lesson plans before the observed lessons as she reflected on her students' struggles to achieve academic outcomes based on the curriculum created by others who do not know her students. We speculate (although she never stated this directly) that as Isabella gained more teaching experience with her learners and was able to reflect on these experiences at the practice stage of the framework, she was also able to gain more insight into why certain plans and activities work more effectively than others. The post-observation interviews along with the sharing of the findings on the practice stage (and indeed all the other stages) allowed Isabella to question what was required by the institution to be covered in her lessons via the mandated textbook so that her students could pass standardized exams run by the institution and what was actually occurring in her lessons, and what could have happened differently as she reflected on the action. During the final stage of Farrell's framework, Isabella reflected on the sociopolitical aspects of teaching English as a foreign language in Costa Rica. She realized that teachers are influenced day to day by society, and in order to create a safe 
environment, she does not discuss topics such sexuality, politics, and religion because she "cannot predict how sensible people are" and the "debates that result would take away from learning." When asked to elaborate, Isabella said that if a comment related to these topics were to come up, she would not discourage it, but rather she would say "it is up to everyone how they want to perceive it, now time to move on." Isabella felt that there is an internal conflict between being an authority figure as a teacher and (her reluctance) expressing her own true beliefs about certain topics, as she said,

I have to be neutral as a teacher and it's difficult. It's happened to me a lot with the topic of feminism which is something that is really hard for me to refrain from saying something; however, sometimes I revert to say I will not tolerate violence. Cause this is personally attacking all female students in the classroom. I don't tell them to be a feminist but not to bring those attitudes to class.

Again, we believe that Isabella is just beginning to make connections between her classroom practices and her principles as well as how she wants to be a professional in her teaching context. She is beginning to question her own assumptions about particular topics and norms perpetuated by society, and how all these are mixed into her teaching as she (re)constructs her own vision of what kind of EFL teacher she wants to be. Thus, the purpose of encouraging EFL teachers to reflect on their practice is not to look for best practice, but to get a holistic view of oneself as a TESOL professional. We believe that the five-stage holistic framework we used as a lens for Isabella to reflect provided her with details about her philosophy, principles, theory, practice, and beyond practice, critical reflection that helped her become more aware of herself as an EFL teacher. As Isabella noted,

There are many conflicts between what I know and what I do. For example, I am not really sure if I believe entirely in the rule-based approach; however, it is something I often recur to. I believe this is an opening for me to reflect on why this happens, what I want to continue doing and also the results that I have obtained doing it. In addition, it is evident that my decisions are highly influenced by my experience as a student, which may not always be right since not all students are like me.

Similar to the case studies outlined in the work of Farrell and Kennedy (2019), and Farrell and Macaplinac (2021) which were based on the same framework, our case study took a deductive approach to reflecting on practice. We encouraged Isabella to reflect from a theory-into-practice and beyond mode, or starting from stage/level 1, philosophy, through the different stages to stage/level 5, beyond practice. We took this theory-driven approach while using the framework mainly because Isabella is a novice teacher who is still building her repertoire of teaching practices, and as such, we thought it would 
be best to begin the reflection process with her philosophy and move through the stages to beyond practice. Others may want to use a different approach such as practice-into-theory, especially for more experienced TESOL teachers. In addition, as was often the case, Isabella would include reflections on more than one stage at a time, and therefore, at times it was difficult to separate each of the stages. However, we decided to report on each stage separately as proposed in the framework. For example, when Isabella reported on her principles during the theory stage, we still added this information to the information we had already accumulated at the principles stage even though we were focusing on the theory stage. This shows that teachers' reflections are holistic in nature and difficult to separate into neat stages or categories, as was the case when we were trying to fit her reflections into any one stage. Nevertheless, we noted that the different stages allowed us as researchers to gather information in incremental phases that would have been otherwise difficult. In addition, we believe that reflection at each of these separate stages also allowed Isabella not to become overwhelmed with too much information at any one time in order to focus on one aspect of reflection at a time.

We note that Isabella's principles about language teaching and learning mainly converged with her classroom practices despite transitioning to an online learning environment in the middle of a semester. Not only is this research valuable for pre-service and in-service teachers, but it is also crucial for teacher-trainers to better prepare teachers for the real world of teaching. Reflective practice connects the teacher-as-person with the act of teaching as teachers are not immune to the moral, political, emotional, ethical, and social issues outside the classroom (Farrell, 2015)

\section{Conclusion}

The value of reflection is that teachers who engage in reflective practice can develop a deeper understanding of their philosophy, principles, and theories as they relate to their actual practices, and thus become proactive and confident in their teaching (Farrell, 2019). Isabella's reflections through the framework for reflecting on practice (Farrell. 2015) have for the most part confirmed that her principles about language teaching and learning mainly converged with her classroom practices despite having to transition to an online learning environment in the middle of a semester. Although generalization is always difficult from case studies such as the one presented in this paper, and this study has limitations such as the small sample size (one teacher), the short duration of data collection (1-month), and the inability to observe teacher practices in-person, there is every reason to believe that readers may find much of Isabella's reflections that were outlined and discussed in this paper have relevance for each teacher's particular context, practices, and reflections. We leave the last words to Isabella: "I had never been questioned in such depth about my classes, and it made me notice things that I can do better, or at 
least ask for help on how to improve (online teaching mostly). Furthermore, having this experience in this particular context helped a lot to navigate more carefully in what I chose my online classes to be."

\section{Acknowledgement}

We would like to acknowledge the dean of Faculty of Social Science, Brock University for providing funds to help with this research.

\section{The Authors}

Thomas S. C. Farrell is professor of applied linguistics at Brock University, Canada. His professional interests include reflective practice, and language teacher education. A selection of his work can be found on his webpage: www.reflectiveinquiry.ca

Vanja Avejic has an MA in Applied Linguistics from Brock University. She is interested in reflective practice in terms of teaching and research.

\section{References}

Akbari, R. (2007). Reflections on reflection: A critical appraisal of reflective practices in L2 teacher education. System, 35, 192-207.

Bartlett, L. (1990). Teacher development through reflective teaching. In J. C. Richards \& D. Nunan (Eds.), Second language teacher education (pp. 202-214). New York: Cambridge University Press.

Collin, S., \& Karsenti, T. (2011). The collective dimension of reflective practice: The how and why. Reflective practice, 12, 569-581.

Farrell, T. S. C. (2015). Promoting teacher reflection in second language education: A framework for TESOL professionals. New York: Routledge.

Farrell, T. S. C. (2018a). Reflective language teaching: Practical applications for TESOL teachers. Bloomsbury Publishing.

Farrell, T. S. C. (2018b). Research on reflective practice in TESOL. Routledge.

Farrell, T. S. C. (2019). Reflective practice in ELT. London, UK: Equinox.

Farrell, T. S. C., \& Kennedy, B. (2019). Reflective practice framework for TESOL teachers: One teacher's reflective journey. Reflective Practice, 20, 1-12.

Farrell, T. S. C. \& Kennedy, J. (2020). My personal teaching principle is 'safe, fun, and clear': Reflections of a TESOL teacher. IJLTR, 8(2) 83-96.

Farrell, T. S. C. \& Macapinlac, M. (2021). Professional development through reflective practice: A framework for TESOL teachers. Canadian Journal of Applied Linguistics, 24(1) 1-25.

Farrell, T. S. C., \& Yang, D. (2019). Exploring an EAP teacher's beliefs and practices in teaching L2 speaking: A case study. RELC Journal, 50(1) 104-117.

Freeman, D. (2016). Educating second language teachers. Oxford University Press.

Hébert, C. (2015). Knowing and/or experiencing: A critical examination of the reflective models of John Dewey and Donald Schön. Reflective Practice, 16, 361-371.

Knezevic, B. (2001). Action research. IATEFL Teacher Development SIG Newsletter 1, 10-12.

Lamb, M. (2007). The impact of school on EFL learning motivation: An Indonesian case-study. TESOL Quarterly, 41(4) 757-780.

Lincoln, Y. S., \& Guba, E. G. (1985). Naturalistic inquiry. Beverly Hills, CA: Sage.

Loughran, J. (2002). Effective reflective practice: In search of meaning in learning about teaching. Journal of Teacher Education, 53(1) 33-43.

Mackey, A., \& Gass, S. M. (2015). Second language research: Methodology and design. Routledge.

Mann, S., \& Walsh, S. (2013). RP or 'RIP': A critical perspective on reflective practice. Applied Linguistics Review, 4(2) 291-315.

Maxwell, J. (1992). Understanding and validity in qualitative research. Harvard Educational 
Review, 62(3) 279-301.

Merriam, S. B. (2009). Qualitative research: A guide to design and implementation (3rd ed.). San Francisco: Jossey-Bass.

Merriam, S. B., \& Tisdell, E. J. (2009). Qualitative data analysis. Qualitative research: A guide to design and implementation. San Francisco: Jossey-Bass.

Pajares, M. F. (1992). Teachers' beliefs and educational research: Cleaning up a messy construct. Review of Educational Research, 62(3) 307-332.

Tabachnik, R., \& Zeichner, K. (2002). Reflections on reflective teaching. In A. Pollard. (Ed.), Readings for Reflective Teaching (pp. 13-16). London: Continuum.

Tsui, A. B. M. (2007). Complexities of Identity formation: A narrative inquiry of an EFL teacher. TESOL Quarterly, 41(4) 657-680.

van Lier L. (2005). Case study. In Hinkel E. (ed.), Handbook of research in second language learning (pp. 195-208). Mahwah, NJ: Lawrence Erlbaum Associates.

Walsh, S., \& Mann, S. (2015). Doing reflective practice: A data-led way forward. ELT Journal, 69(4) 351-362.

Wright, T. (2010). Second language teacher education: Review of recent research on practice. Language Teaching 43(3) 259-296.

Zeichner, K. M., \& Liston, D. P. (2014). Reflective teaching: an introduction. $2^{\text {nd }}$ ed. New Jersey: Lawrence Erlbaum.

Zwozdiak-Myers, P. (2012). The teacher's reflective practice handbook. Becoming an extended professional through capturing evidence-informed practice. London and New York: Routledge. 